\title{
Uncurtaining the effect of COVID-19 in diabetes mellitus: a complex clinical management approach
}

\author{
Shilpi Kashyap ${ }^{1} \cdot$ Rajni Bala ${ }^{2} \cdot$ Reecha Madaan ${ }^{2} \cdot$ Tapan Behl $^{2}$ \\ Received: 26 March 2021 / Accepted: 14 May 2021 / Published online: 21 May 2021 \\ (C) The Author(s), under exclusive licence to Springer-Verlag GmbH Germany, part of Springer Nature 2021
}

\begin{abstract}
The aim of the present review is to overview the common properties of corona virus and hence proofs well beginning of corona virus in persons with diabetes, and its treatment. Globally, it has been observed that according to the statistics, India has the second largest number of people with diabetes. Literature review has been implemented within the databases using suitable keywords. For persons suffering from diabetic disorder, the COVID-19 infection becomes a dual challenge. Diabetes is a severe metabolic situation which causes the sugar levels in the blood to increase than the normal level. Normally, communicable disease like COVID-19 is more prevailing in patients with diabetes. Diabetic patient has poor immune response to infections. The different bacterial, viral, parasitic, and mycotic infections showed increased probability in diabetic patients as compared to non-diabetic patient. All these conclusions clear out the intention that the diabetic patients are more susceptible to enhanced inflammatory response that may lead to rapid spreading of COVID-19 infection with high rate of mortality. In the present situation of pandemic, managing diabetes seems to be quite challenging and diabetic patient having COVID-19 infection should follow normal course of antihypertensive and antidiabetic drugs prescribed with the exception of sodium glucose co-transpoters2 inhibitors which would increase the risk of dehydration and ketoacidosis. In view of above discussion, this article highlights the proposed mechanism of COVID-19 infection linking it with diabetes, antidiabetic drugs to be used in COVID-19 infection along with their advantages, and disadvantages and management of COVID-19 infection diabetic patient.
\end{abstract}

Keywords COVID-19 $\cdot$ Diabetes mellitus $\cdot$ Pathogenesis $\cdot$ Clinical management

\section{Introduction}

Corona virus disease is caused by corona virus Severe Acute Respiratory Syndrome (SARS)-COVID-2 that have been quickly spread in near about 160 countries all over the world. On average, 6-8 days is its incubation time, following 1-2 weeks of symptomatic disease. COVID-19 being highly infectious disease. It spreads person-to-person through close contact with someone who is infected with the virus. COVID-19 symptoms can appear from 2 to 14 days after being exposed, which includes cough, body temperature, myalgia, pneumonia which is a viral infection, and failure of

Responsible Editor: Lotfi Aleya

Rajni Bala

rajni.bala@chitkara.edu.in

1 Pharmaceutics, Himachal Institute of Pharmacy, Paonta Sahib, India

2 Chitkara College of Pharmacy, Chitkara University, Punjab, India respiration. In severe situations, it also leads to death (Del Rio and Malani 2020). A family of disease which is called as diabetes type 1 and 2 is characterized by high blood sugar level where body either fails to make enough insulin or unable to use insulin effectively. (otherwise known as high or blood glucose) (Yang et al. 2020a, b). Approximately 425 million people at present across the world have diabetes of which $10 \%$ cases are of type 1 and rest 90-95\% are of type 2. The sugar builds up in the plasma when our body does not make any or enough of the insulin that aids in the body to gain sugar into the cells for source of energy (Guan et al. 2020). Another usual type is type 2 diabetes, in which the body does not make enough of glucose or appropriately use the insulin it has (Yang et al. 2020a, b). In diabetes management, healthy nutrition is an essential component which is important for patients with diabetes to have a different and balanced diet to stabilize their blood glucose levels and enhance their immune system (Zhang et al. 2020). Among those with severe COVID-19, there is a severity of concomitant conditions such as diabetes, cardiovascular disease, hypertension, obesity, and 
chronic obstructive pulmonary disease (COPD) (Ruan et al. 2020)

People above the age of sixty and people with pre-existing diseased status, such as diabetes, heart disease, and asthmatic conditions, appear to be more expected to become infected and severely ill by COVID-19 virus (Bontempi 2020). The reason for this is that if a diabetic individual gets infected with virus, it is difficult to maintain fluctuating blood sugar level because of diabetes complications, first in this condition immune system is weak and therefore not able to fight with viral infection and secondly virus grows well in the presence of increased blood sugar level.

There is an evidence that due to COVID-19, there occurs acute respiratory distress syndrome (ARDS) and respiratory failure, caused by a defective immune response, symptomized by a rapid proliferation and hyper activation of $\mathrm{T}$ cells, macrophages, (Zhou et al. 2020) natural killer cells, and an over production of chemical mediators (the so called cytokines storm), including pro-inflammatory cytokines (Leung 2020) and chemokines leading to an enhanced vascular permeability with the failure of multiple-organs (Wu et al. 2020a).

Pathogenetic link between COVID-19 infection and diabetes has impact on glucose homeostasis, immune status, inflammation, and renin angiotensin aldosterone system. Various therapeutic agents used in the management of COVID-19 infection may disturb the glucose metabolism, so in order to lower down the rate susceptibility and to reduce the serious outcomes of COVID-19 infection in a diabetic individual, a strict control and monitoring of glucose level has to be done. Various studies related to this suggest that insulin and dipeptidyl peptides -4 inhibitors are drug of choice in order to reduce the severe complications. Since till date there is no definite therapy against COVID-19 infection, therefore, the objective of the presented review is to discuss general clinical guidelines a diabetic patient should follow to maintain glucose level for the management of COVID- 19 infection which includes daily physical activity and maintaining healthy diet along with antidiabetic drugs.

\section{COVID-19 infection: mechanism}

Corona virus is infecting humans since long time as it is the same virus which is responsible for causing the common cold. It is a transferable viral infection that primarily spread through the droplets present in the air discharged by infected person in open air as a result of coughing and sneezing which are then inhaled by healthy individual or by touching the articles in contact with infected person (Byass 2020). The genome of corona virus formed of approximately 30000 nucleotides. It identifies four structural proteins, nucleocapsid $(\mathrm{N})$ protein, membrane $(\mathrm{M})$ protein, spike (S) protein, and envelop (E) protein and many other non-structural proteins (Cai 2020). The protein shell of virus is capsid that contains its genetic material and N-protein that binds to the virus single positive strand RNA to allow the virus to have a control over human cells and turn them into viral factories $(\mathrm{Li}$ et al. 2020a; Fisher et al. 2020). The N protein envelops the viral RNA genome and plays important role in viral replication and transcription. Membrane (M) protein is present on the viral surface and regulate the organization of corona virus assembly. The S-protein is antigen component which is responsible for inducing host immune response and attachment of the virus to the host cell surface receptors and that allows virus to enter into the host cell. E protein is small membrane protein and is responsible for viral assembly, membrane permeability of host cell, and viral and host cell interaction (Yang et al. 2020a, b). The mechanism involved in the entry of virus causing Corona infection into human cells followed by its replication and RNA packing is outlined in (Cave 2020; Hung et al. 2004) Fig. 1.

The corona virus spike $(\mathrm{S})$ protein binds to angiotensin converting enzyme 2 (ACE2) receptors found on the surface of many human cells, involving those in the lungs make it possible for virus to get assess in to human cells to induce proteolytic cleavages by host proteases (Chen et al. 2020a, b) (i.e., trypsin and furin), at the interface of S1, S2 subunits, after this cleavage of the S2 domain occur in order to release the fused peptide (Schoen et al. 2019; He et al. 2020).

\section{Relationship between COVID-19 and diabetes}

The relation between diabetes mellitus and the projection of COVID-19 infection can be studied via comparing data from diabetes and non-diabetes groups. In various investigations, it has been found that diabetic individuals elicit high level of neutrophils (Davies et al. 2020; Eslami and Jalili 2020; Fan et al. 2020), C-reactive protein, procalcitonin, and D-dimer, and lower levels of lymphocytes and albumin among in comparison to non-diabetic individuals. Further, there are significantly higher incidence of bilateral pneumonia, respiratory distress, acute cardiac injury, and death seen in diabetic patient. Observations suggested diabetes to be an independent risk factor for the projection of COVID-19 (Wang et al. 2020a; Liu et al. 2020b). Risk of progression of disease seemed higher and prediction appeared worse following the infection of severe acute respiratory syndrome corona virus 2 (SARS-CoV-2) among patients with diabetes requiring insulin (Ferlita et al. 2019; Yao et al. 2020).

\section{Various mechanisms linking diabetes to Corona virus infection}

Different proposed mechanisms for understanding the negative effect of diabetes in Corona virus infected individual are summarized in Fig. 2 which includes elevated blood glucose 


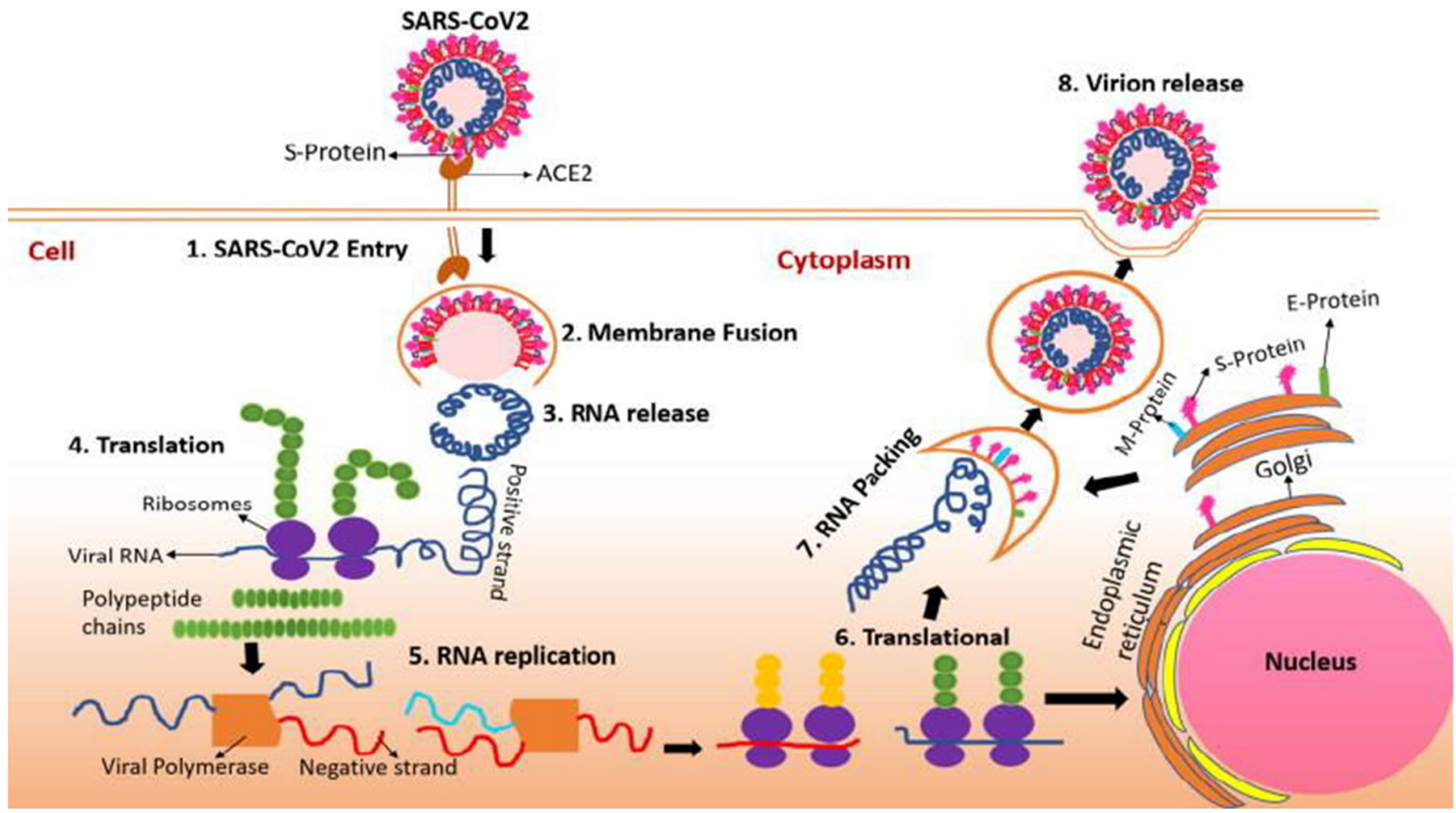

Fig. 1 The proposed process of entry of a virus followed by replication process and packing of RNA in the human cell

level along with accompanying imbalance in the pathway involved in viral cell entry, decreases clearance of virus, poor functioning of $\mathrm{T}$ Cells, increased susceptibility to hyper inflammation due to release of higher amount of inflammatory cytokines, and finally complications related to diabetes such as cardiovascular disease (Critchley et al. 2018; Wu et al. 2020b; Zietz and Tatonetti 2020).

\section{Antidiabetic drugs in COVID-19 infection}

Different considerations for patients with COVID-19 might raise use of antidiabetic agents. In an out-patient having mild

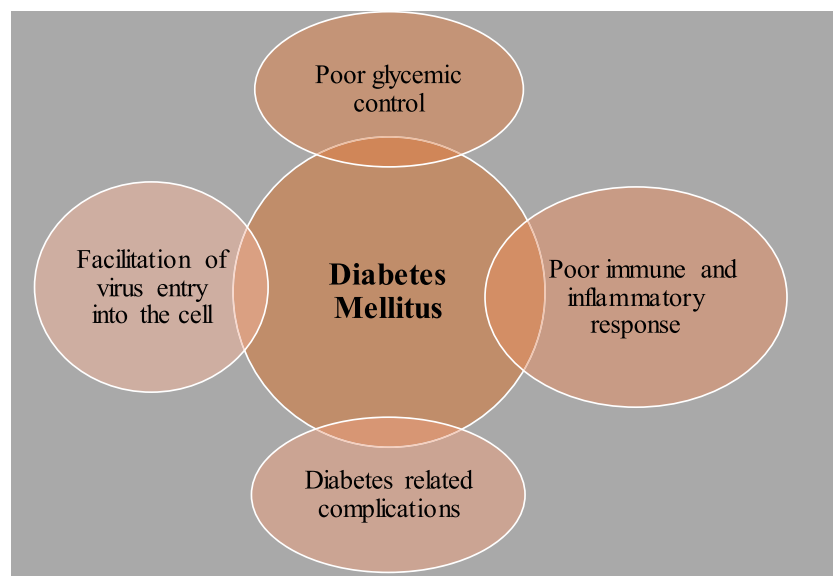

Fig. 2 Different proposed mechanisms describing the negative impact of diabetes in Corona virus infection
COVID-19 infection, with diabetes, usual glucose-lowering therapies could be continued (Huttunen and Syrjänen 2013; Pal et al. 2020). Gliptins also called as dipeptidyl-peptidase 4 (DPP-4) may be considered as they have some potential of preventing clinical course of COVID-19 infection as they have positive impact on modulation of viral entry and overproduction of cytokines. Other antidiabetic drugs such as sodium glucose co-transporter 2 (SGLT-2) may likelihood to increase the risk by inducing ketoacidosis in already insulindeficient condition therefore required to be stopped. Potential advantages and disadvantages of some of the novel antidiabetic drug in covid-19 infection are discussed in Table 1.

\section{Management for COVID-19}

Standard care should be followed for the proper management of Corona virus infection. It puts forward a special challenge for those with preexisting endocrinopathy, especially for diabetes. The special care should be taken to maintain hormonal imbalance in persons on hormonal replacement or supplementation therapy (Hartzband and Groopman 2020; Han et al. 2020). Corticosteroids, for example, can cause instability in maintaining blood sugar level means it may induce either hypo or hyperglycemia, and on the other side, long-term use of antiretroviral may be associated with metabolic syndrome. Proper care should be taken while choosing parenteral nutrition: a balance must be maintained between calorie intake, nutrient intake balance, and sleep to achieve proper control 
Table 1 Antidiabetic drugs for COVID-19 diabetic complication (Honce and Schultz-Cherry 2019; Almond et al. 2020; Dixon and Peters 2020; Wan et al. 2020; Hoffmann et al. 2020; Li et al. 2017; Spiegel et al. 1983; Zhu et al. 2020)

\begin{tabular}{|c|c|c|c|c|}
\hline Drug & Efficacy & Safety & $\begin{array}{l}\text { Indications for Covid-19 } \\
\text { treatment }\end{array}$ & Reference \\
\hline $\begin{array}{l}\text { GLP1 } \\
\text { receptor } \\
\text { agonist }\end{array}$ & $\begin{array}{l}\text { Increased glucose lowering effect, } \\
\text { modest weight loss, low risk } \\
\text { of hypoglycemia }\end{array}$ & $\begin{array}{l}\text { Nausea, vomiting, diarrhea, risk } \\
\text { of acute pancreatitis as per } \\
\text { warning issued by FDA }\end{array}$ & $\begin{array}{l}\text { Improved clinical outcomes } \\
\text { and proved beneficial due } \\
\text { anti-inflammatory and } \\
\text { anti-obesogenic properties. }\end{array}$ & Belančić et al. 2021 \\
\hline $\begin{array}{l}\text { DPP-4 } \\
\quad \text { inhibitors }\end{array}$ & $\begin{array}{l}\text { Moderate glucose lowering effect, does } \\
\text { not affect body weight and } \\
\text { less risk of hypoglycemia }\end{array}$ & $\begin{array}{l}\text { Risk of acute pancreatitis as } \\
\text { per warning issued by FDA }\end{array}$ & $\begin{array}{l}\text { Reduce severity of COVID-19 } \\
\text { infection }\end{array}$ & $\begin{array}{l}\text { De Vries and } \\
\text { Rosenstock } \\
2017\end{array}$ \\
\hline $\begin{array}{l}\text { SGLT2- } \\
\text { inhibitors }\end{array}$ & $\begin{array}{l}\text { Moderate glucose lowering effect } \\
\text { and body weight, low risk of } \\
\text { hypoglycemia }\end{array}$ & $\begin{array}{l}\text { High risk of occurrence of } \\
\text { genitourinary infection, not } \\
\text { recommended in eGFR } \\
<45 \mathrm{~min} / \mathrm{ml}\end{array}$ & $\begin{array}{l}\text { Increase the risk of euglycemic } \\
\text { diabetic ketoacidosis } \\
\text { (euDKA) } \\
\text { in acute COVID-19 illness. }\end{array}$ & Kalra et al. 2020. \\
\hline
\end{tabular}

over blood glucose level (Brancatella et al. 2020; Hultström et al. 2020; Luo et al. 2020). All management for diabetic patient with corona virus infection should follow the principles of investigative parsimony and therapeutic parsimony (Ornstein et al. 2020; Zhang et al. 2020). According to these systems, the minimum number of investigations, drugs, drug combination, dose, and dosing frequency to be used in order to have optimal therapeutic results (Chen et al. 2020a; Kronbichler et al. 2020). Although it is difficult to apply these principals in diabetes as it is metabolic disorder that is associated with multiple pathophysiological abnormalities because of which it is difficult to maintain blood sugar level, but with availability of recent fixed dose combination and therapeutic agents having broad spectrum of glucometabolic control allows the proper management of diabetes (Lai et al. 2020; Li et al. 2020b).

\section{The public health management}

In order the treat severely ill patients, measurement of endocrine status can be taken as a tool for public health management, especially for those suffering from diabetes, along with the elderly individuals above 60 years of age, they are asked to self-isolate and restrict their movement in view of their increased susceptibility (Casqueiro et al. 2012; Gupta et al. 2020; Oliveiros et al. 2020). In the same way for those which require chronic endocrine/metabolic care, for example in case of underactive thyroid functioning, metabolic bone disorder or gonadal disease are advised to avoid routine hospital visits (Pivonello et al. 2016; Haramoto et al. 2020). Such measures will help reduce exposure of susceptible individuals to the COVID-19 virus, and slow down frequency of mass spreadability (Otter et al. 2016; Wang et al. 2020b). The COVID-19 pandemic is an ill-fated development for world health (Jiang and Rajagopal 2020; Xie and Zhu 2020; Zheng et al. 2020a).
The link between endocrinology and COVID-19 is depicted in Fig. 3.

\section{Prevention}

COVID-19 virus communicates via small drops that spread into the environment when an infected sneezes or coughs. Any person who is approachable at 6 feet of this infected person can come in contact with these droplets (El-Farhan et al. 2017; Mohammadi et al. 2020). COVID-19 may even spread from touching the frequently touched surfaces the infected person may have touched. Diabetic patients can take precautions and save themselves from COVID-19 infection by (Laffel 2000; Bornstein et al. 2016; Qin et al. 2019; Umpierrez and Pasquel 2017; Tandon et al. 2017; Prajapat et al. 2020) washing hands frequently, avoiding contact with infected person and surfaces that were touched by others, regularly cleaning and disinfecting potentially contaminated surfaces like tabletops, door handles, countertops, etc., and not touching the mouth, eyes, or nose, with unwashed hands; follow social distancing — staying at least 6 feet away from anyone in public places; avoiding any contact with sick people, especially with those having fever, cough, or both; getting at least 7-h sleep at night to keep the immune system strong and reducing the stress level as much as possible; and maintaining suitable intake of fluids and food but ensuring that this is as per the diet plan to keep good control over the blood sugar levels (Liu et al. 2020a; Zhao et al. 2020).

\section{Future prospects and conclusion}

An upcoming upliftment is immediately required for a proper systematic understanding of the differences in predispositions of genetics among different populations, that undergoes patho-physiological mechanisms. Hence, a foremost 


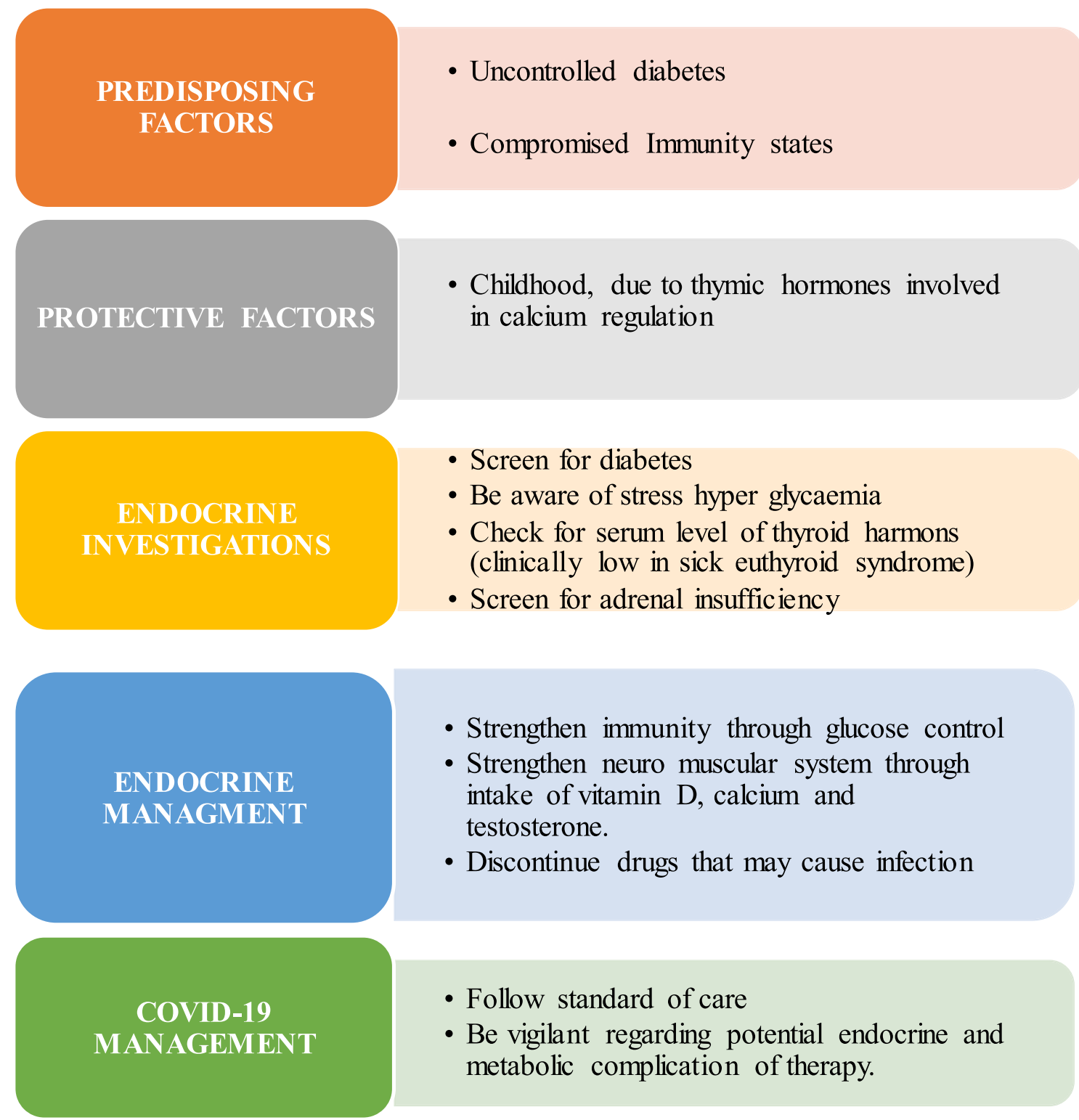

Fig. 3 Endocrinology and COVID-19 - the link (Bar-Or et al. 2019; Ortega Chavarría et al. 2019; Ellger et al. 2005)

informative and knowledgeable research in this relationship and in its management must be warranted. All over the world, in more than 200 countries or territories, there exists greater than $14,650,000$ confirmed cases, with more than 600,000 deaths. An evidence of people with diabetes which is increased by two to three-folds are more likely to cause hike in the death rate because of this pandemic (Prajapat et al. 2020; Zheng et al. 2020b; Singhal 2020; Yi and Kang 2017). It can be concluded that though diabetic patients are at risk of more severe medical complications from COVID19 , it is possible to decrease the risk by maintaining good control over the blood sugar levels and following COVID19 infection prevention measures (Lescure et al. 2020; Medema et al. 2020). To maintain a balanced glucose control is important, as both higher and lower level of blood glucose level are associated with enhanced inflammatory responses and acute cardiovascular event. The different glucoselowering and anti-inflammatory agents such as insulin and GLP-1RAs, alone or in combination, represent a strong therapeutic approach to treat asymptomatic and non-critically ill COVID-19 diabetic patients. However, more prospective and detailed studies are required to evaluate the use of these glucose-lowering injective agents and correlate them with better outcomes that lowers the rate of morbidity and mortality with respect to SARS-CoV-2.

Author contribution Literature review done by SA, designing and lay out by RM, manuscript writing and compilation by R B, and final review and editing was done by $\mathrm{T} \mathrm{B}$. 
Data availability Not applicable.

\section{Declarations}

Ethics approval Not applicable.

Consent to participate Not applicable.

Consent for publication All the authors have approved the manuscript for publication.

Competing interests The authors declare no competing interests.

\section{References}

Almond MH, Edwards MR, Barclay WS, Johnston SL (2020) Obesity and susceptibility to severe outcomes following respiratory viral infection. Thorax 68:684-686. https://doi.org/10.1111/obr.13083

Bar-Or D, Rael LT, Madayag R (2019) Stress hyperglycemia in critically ill patients: insight into possible molecular pathways. Front Med 54: 1-5. https://doi.org/10.3389/fmed.2019.00054

Belančić A, Kresović A, Troskot Dijan M (2021) Glucagon-like peptide1 receptor agonists in the era of COVID-19: Friend or foe? Clin Obes 11:1-6. https://doi.org/10.1111/cob.12439

Bontempi E (2020) First data analysis about possible COVID-19 virus airborne diffusion due to air particulate matter (PM): the case of Lombardy (Italy). Environ Res 186:109639. https://doi.org/10. 1016/j.envres.2020.109639

Bornstein SR, Allolio B, Arlt W (2016) Diagnosis and treatment of primary adrenal insufficiency: an endocrine society clinical practice guideline. J Clin Endocrinol Metab 101:364-389. https://doi.org/ 10.1210/jc. $2015-1710$

Brancatella A, Ricci D, Viola N (2020) Subacute thyroiditis after SARSCov-2 infection. J Clin Endocrinol Metab 105:276. https://doi.org/ 10.1210/clinem/dgaa276

Byass P (2020) Eco-epidemiological assessment of the COVID-19 epidemic in China, January-February 2020. Glob Health Action 13: 1760490. https://doi.org/10.1101/2020.03.29.20046565

Cai G (2020) Bulk and single-cell transcriptomics identify tobacco-use disparity in lung gene expression of ACE2, the receptor of 2019nCov. Med Rxiv. https://doi.org/10.1101/2020.02.05.20020107.

Casqueiro J, Casqueiro J, Alves C (2012) Infections in patients with diabetes mellitus: a review of pathogenesis. Indian J Endocr Metab 16:S27-S36. https://doi.org/10.4103/2230-8210.94253

Cave E (2020) COVID-19 super-spreaders: definitional quandaries and implications. Asian Bioethics Rev. 12:1-8. 10.1007/ s41649-02000118-2.

Chen N, Zhou M, Dong X (2020a) Epidemiological and clinical characteristics of 99 cases of 2019 novel coronavirus pneumonia in Wuhan, China: a descriptive study. Lancet 395:507-513. https:// doi.org/10.1016/S0140-6736(20)30211-7

Chen Y, Chen L, Deng Q, Zhang G, Wu K, Ni L, Yang J (2020b) The presence of SARS CoV2 RNA in the feces of COVID-19 patients. J Med Virol 92:833-840. https://doi.org/10.1002/jmv.25825

Critchley JA, Carey IM, Harris T (2018) Glycemic control and risk of infections among people with type 1 or type 2 diabetes in a large primary care cohort study. Diabetes Care 10:2127-2135. https://doi. org $/ 10.2337 / \mathrm{dc} 18-0287$

Davies NG, Klepac P, Liu Y (2020) Age-dependent effects in the transmission and control of COVID-19 epidemics. Nat Med 26:12051211. https://doi.org/10.1038/s41591-020-09629
De Vries JH, Rosenstock J (2017) DPP-4 inhibitor-related pancreatitis: rare but real! Diabetes Care 40:161-163. https://doi.org/10.2337/ dci16-0035

Del Rio C, Malani PN (2020) COVID-19-new insights on a rapidly changing epidemic. JAMA. 232:1339-1340. https://doi.org/10. 1001/jama.2020.3072

Dixon AE, Peters U (2020) The effect of obesity on lung function. Expert Rev Respir Med 12(9):755-767. https://doi.org/10.1080/17476348. 2018.1506331

El-Farhan N, Rees DA, Evans C (2017) Measuring cortisol in serum, urine and saliva - are our assays good enough. AnnClin Biochem 54:308-322. https://doi.org/10.1016/S2213-8587(20)30305-3

Ellger B, Debaveye Y, Van den Berghe G (2005) Endocrine interventions in the ICU. Eur J Intern Med 16:71-82. https://doi.org/10.1016/j. ejim.2004.10.014

Eslami H, Jalili M (2020) The role of environmental factors to transmission of SARS-CoV-2 (COVID-19). AMB Express 10:92. https:// doi.org/10.1186/s13568-020-01028-0

Fan Q, Zhang W, Li B, Li D-J, Zhang J, Zhao F (2020) Association between ABO Blood Group System and COVID-19 susceptibility in Wuhan. Front Cell Infect Microbiol 10:404. https://doi.org/10. 3389/fcimb.2020.00404

Ferlita S, Yegiazaryan A, Noori N (2019) Type 2 diabetes mellitus and altered immune system leading to susceptibility to pathogens, especially mycobacterium tuberculosis. J Clin Med 16:2219. https://doi. org/10.3390/jcm8122219

Fisher D, Reilly A, Zheng A, Cook A, Anderson D (2020) Seeding of outbreaks of COVID-19 by contaminated fresh and frozen food. BioRxiv. https://doi.org/10.1101/2020.08.17.255166.

Guan WJ, Ni ZY, Hu Y (2020) Clinical characteristics of corona virus disease 2019 in China. N Engl J Med 382:1708-1720. https://doi. org/10.1056/NEJMoa2002032

Gupta S, Raghuvanshi GS, Chanda A (2020) Effect of weather on COVID-19 spread in the US: a prediction model for India in 2020. Sci Total Environ 728:138860. https://doi.org/10.1016/j.scitotenv. 2020.138860

Han MS, Seong MW, Heo EY, Park JH, Kim N, Shin S, Choi EH (2020) Sequential analysis of viral load in a neonate and her mother infected with SARS-CoV-2. Clin Infect Dis 71:2236-2239. https://doi.org/ 10.1093/cid/ciaa447

Haramoto E, Malla B, Thakali O, Kitajima M (2020) First environmental surveillance for the presence of SARS-CoV-2 RNA in wastewater and river water in Japan. medRxiv. https://doi.org/10.1101/2020.06. 04.20122747.

Hartzband P, Groopman J (2020) Physician burnout, interrupted. N Engl J Med 382:2485-2487. https://doi.org/10.1056/NEJMp2003149

He Z, Chin Y, Huang J, He Y, Akinwunmi BO, Yu S, Ming WK (2020) Meteorological factors and domestic new cases of coronavirus disease (COVID-19) in nine Asian cities: a time-series analysis. medRxiv. https://doi.org/10.1101/2020.04.15.20066613.

Hoffmann M, Kleine-Weber H, Schroeder S et al (2020) SARS-CoV-2 cell entry depends on ACE2 and TMPRSS2 and is blocked by a clinically proven protease inhibitor. Cell. 181:271-280e8. https:// doi.org/10.1016/j.cell.2020.02.052

Honce R, Schultz-Cherry S (2019) Impact of obesity on influenza a virus pathogenesis, immune response, and evolution. Front Immunol. https://doi.org/10.3389/fimmu.2020.01071

Hultström M, Persson B, Eriksson O, Lipcsey M, Frithiof R, Nilsson B (2020) Blood type A associates with critical COVID-19 and death in a Swedish cohort. Crit Care 24:496. https://doi.org/10.1186/s13054020-03223-8

Hung IF, Cheng VC, Wu AK, Tang BS, Chan KH, Chu CM, Wong MM, Hui WT, Poon LL, Tse DM et al (2004) Viral loads in clinical specimens and SARS manifestations. Emerg Infect Dis 10:1550 1557. https://doi.org/10.3201/eid1009.040058 
Huttunen R, Syrjänen J (2013) Obesity and the risk and outcome of infection. Int J Obes 37:333-340. https://doi.org/10.1038/ijo.2012. 62

Jiang S, Rajagopal R (2020) Classification and diagnosis of diabetes: standards of medical care in diabetes-2020. Diabetes Care 43(Suppl 1):S14-S31. https://doi.org/10.2337/dc20-s002

Kalra S, Shetty KK, Nagarajan VB, Ved JK (2020) Basic and clinical pharmaco-therapeutics of SGLT2 inhibitors: a contemporary update. Diabetes Ther: Research, Treatment and Education of Diabetes and Related Disorders 11:813-833. https://doi.org/10. 1007/s13300-020-00789

Kronbichler A, Kresse D, Yoon S, Lee KH, Effenberger M, Shin JI (2020) Asymptomatic patients as a source of COVID-19 infections: a systematic review and meta-analysis. Int J Infect Dis 98:180-186. https://doi.org/10.1016/j.ijid.2020.06.052

Laffel L (2000) Sick-day management in type 1 diabetes. Endocrinol Metab Clin N Am 29:707-723. https://doi.org/10.1016/S08898529(05)70160-2

Lai S, Bogoch II, Ruktanonchai NW, Watts A, Lu X, Yang W, Tatem AJ (2020) Assessing spread risk of Wuhan novel coronavirus within and beyond China, January-April 2020: a travel network-based modelling study. medRxiv. https://doi.org/10.1101/2020.02.04. 20020479.

Lescure FX, Bouadma L, Nguyen D, Parisey M, Wicky PH, Behillil S, Enouf V (2020) Clinical and virological data of the first cases of COVID-19 in Europe: a case series. Lancet Infect Dis 20:697-706. https://doi.org/10.1016/S1473-3099(20)30200-0

Leung C (2020) Clinical features of deaths in the novel corona virus epidemic in China. Rev Med Virol. https://doi.org/10.1002/rmv. 2103.

Li XC, Zhang J, Zhuo JL (2017) The vasoprotective axes of the reninangiotensin system: physiological relevance and therapeutic implications in cardiovascular, hypertensive and kidney diseases. Pharmacol Res Pharmacol Res 11:12521-12538. https://doi.org/ 10.1016/j.phrs.2017.06.005

Li B, Yang J, Zhao F (2020a) Prevalence and impact of cardiovascular metabolic diseases on COVID-19 in China. Clin Res Cardiol 109: 531-538. https://doi.org/10.1007/s00392-020-01626-9

Li J, Zhang L, Ren Z, Xing C, Qiao P, Chang B (2020b) Meteorological factors correlate with transmission of 2019-nCoV: proof of incidence of novel coronavirus pneumonia in Hubei Province, China. medRxiv. https://doi.org/10.1101/2020.04.01.20050526.

Liu Y, Mao B, Liang S, Yang JW, Lu HW, Chai YH, Wang L, Zhang L, Li QH, Zhao L, He Y, Gu XL, Ji XB, Li L, Jie ZJ, Li Q, Li XY, Lu HZ, Zhang WH, Song YL, Shanghai Clinical Treatment Experts Group for COVID-19 (2020a) Association between age and clinical characteristics and outcomes of COVID-19. Eur Respir J 55: 2001112. https://doi.org/10.1183/13993003.01112-2020

Liu Y, Ning Z, Chen Y, Guo M, Liu Y, Gali NK, Liu X (2020b) Aerodynamic characteristics and RNA concentration of SARSCoV-2 aerosol in Wuhan hospitals during COVID-19 outbreak. BioRxiv. https://doi.org/10.1101/2020.03.08.982637v1.

Luo W, Majumder MS, Liu D, Poirier C, Mandl KD, Lipsitch M, Santillana M (2020) The role of absolute humidity on transmission rates of the COVID-19 outbreak. MedRxiv. https://doi.org/10.1101/ 2020.02.12.20022467.

Medema G, Heijnen L, Elsinga G, Italiaander R, Brouwer A (2020) Presence of SARS-Coronavirus-2 in sewage. medRxiv. 10.1101/ 2020.03.29.20045880.

Mohammadi M, Meskini M, do Nascimento Pinto AL (2020) Novel coronavirus (COVID-19) overview. J Public Health. 10.1007/ s10389-020-01258-3.

Oliveiros B, Caramelo L, Ferreira NC, Caramelo F (2020) Role of temperature and humidity in the modulation of the doubling time of COVID-19 cases. medRxiv. https://doi.org/10.1101/2020.03.05. 20031872 .
Ornstein SR, Rubino F, Khunti K (2020) Practical recommendations for the management of diabetes in patients with COVID-19. Lancet Diabetes Endocrinol 8:546-550

Ortega Chavarría MJ, Arredondo S, Daniel A (2019) Sick euthyroid syndrome. Acta Médica Grupo Ángeles 17:131-136. https://doi. org/10.1016/S2213-8587(20)30152-2

Otter JA, Donskey C, Yezli S, Douthwaite S, Goldenberg SD, Weber DJ (2016) Transmission of SARS and MERS coronaviruses and influenza virus in healthcare settings: the possible role of dry surface contamination. J Hosp Infect 92:235-250. https://doi.org/10.1016/ j.jhin.2015.08.027

Pal M, Berhanu G, Desalegn C, Kandi V (2020) Severe acute respiratory syndrome coronavirus-2 (SARS-CoV-2): an update. Cureus 12(3): e7423. https://doi.org/10.7759/cureus.7423

Pivonello R, Isidori AM, De Martino MC (2016) Complications of Cushing's syndrome: state of the art. Lancet Diabetes Endocrinol 4:611-629. https://doi.org/10.1016/S2213-8587(16)00086-3

Prajapat M, Sarma P, Shekhar N (2020) Drug targets for corona virus: a systematic review. Indian J Pharm 52:56-65. https://doi.org/10. 4103/ijp.IJP.115-20

Qin J, Deng X, Wei A (2019) Correlation between hypocalcemia and acute exacerbation of chronic obstructive pulmonary disease in the elderly. Postgrad Med 131:319-323. https://doi.org/10.12998/wjcc. v7.i19.3111

Ruan Q, Yang K, Wang W (2020) Clinical predictors of mortality due to COVID-19 based on an analysis of data of 150 patients from Wuhan, China. Intensive Care Med. https://doi.org/10.1007/ s00134-020-05991

Schoen K, Horvat N, Guerreiro NFC (2019) Spectrum of clinical and radiographic findings in patients with diagnosis of $\mathrm{H} 1 \mathrm{~N} 1$ and correlation with clinical severity. BMC Infect Dis 19:964. https://doi.org/ 10.1186/s12879-019-4592-0

Singhal T (2020) A review of corona virus disease-2019 (COVID-19). Indian J Pediatr 87:281-286. https://doi.org/10.1007/s12098-02003263-6

Spiegel JS, Rubenstein LV, Scott B (1983) Who is the primary physician. N Engl J Med 19:654-663. https://doi.org/10.1111/j.1525-1497. 2004.30535

Tandon N, Kalra S, Balhara YP (2017) Forum for injection technique and therapy expert recommendations. India: the Indian recommendations for best practice in insulin injection technique Indian $\mathrm{J}$ Endocr Metab 21:600-617. https://doi.org/10.4103/ijem.IJEM_ 9717

Umpierrez GE, Pasquel FJ (2017) Management of inpatient hyperglycemia and diabetes in older adults. Diabetes Care 40:509-517. https:// doi.org/10.1097/01.CCN.0000532362.87484.62

Wan Y, Shang J, Graham R (2020) Receptor recognition by the novel coronavirus from Wuhan: an analysis based on decade-long structural studies of SARS coronavirus. J Virol 94:e00127-e00120. https://doi.org/10.1128/JVI.00127-20

Wang J, Luo Q, Chen R, Chen T, Li J (2020a) Susceptibility analysis of COVID-19 in smokers based on ACE2. 10.20944/202003.0078.

Wang M, Jiang A, Gong L, Luo L, Guo W, Li C, Zheng J, Li C, Yang B, Zeng J, Chen Y, Zheng K, Li H (2020b) Temperature significant change COVID-19 transmission in 429 cities. MedRxiv. https://doi. org/10.1101/2020.02.22.20025791.

Wu C, Chen X, Cai Y (2020a) Risk factors associated with acute respiratory distress syndrome and death in patients with coronavirus disease 2019 pneumonia in Wuhan, China. JAMA Intern Med. https:// doi.org/10.1001/jamainternmed.2020.0994.

Wu F, Xiao A, Zhang J, Gu X, Lee WL, Kauffman K, Duvallet C (2020b) SARS-CoV-2 titers in wastewater are higher than expected from clinically confirmed cases. medRxiv. https://doi.org/10.1101/2020. 04.05.20051540. 
Xie J, Zhu Y (2020) Association between ambient temperature and COVID-19 infection in 122 cities from China. Sci Total Environ 724:138201. https://doi.org/10.1016/j.scitotenv.2020.138201.

Yang J, Zheng Y, Gou (2020a) Prevalence of co morbidities in the novel Wuhan corona virus (COVID-19) infection: a systematic review and meta-analysis. Int J Infect Dis 94:91-95. https://doi.org/10.1016/j. ijid.2020.03.017

Yang JK, Feng Y, Yuan MY (2020b) Plasma glucose levels and diabetes are independent predictors for mortality and morbidity in patients with SARS. Diabetes Care Jul 43:1399-1407. https://doi.org/10. 2337/dc20-0660

Yao Y, Pan J, Liu Z, Meng X, Wang W, Kan H, Wang W (2020) No association of COVID-19 transmission with temperature or UV radiation in Chinese cities. Eur Respir J 55:2000517. https://doi.org/ 10.1183/13993003.00517-2020

Yi D, Kang YH (2017) Drug-induced diabetes mellitus. J Korean Diabetes 18:160-168. https://doi.org/10.4093/jkd.2017.18.3.160

Zhang JJ, Dong X, Cao YY (2020) Clinical characteristics of 140 patients infected with SARS-CoV-2 in Wuhan, China. Allergy 75:1730 1741. https://doi.org/10.1111/all.14238

Zhao Q, Meng M, Kumar R, Wu Y, Huang J, Lian N, Lin S (2020) The impact of COPD and smoking history on the severity of COVID-19: a systemic review and meta-analysis. J Med Virol 92:1915-1921. https://doi.org/10.1002/jmv.25889
Zheng YY, Ma YT, Zhang JY, Xie X (2020a) COVID-19 and the cardiovascular system. Nat Rev Cardiol 17:259-260. https://doi.org/ 10.1038/s41569-020-0360-5

Zheng Z, Peng F, Xu B, Zhao J, Liu H, Peng J, Ye C (2020b) Risk factors of critical \& mortal COVID-19 cases: a systematic literature review and meta-analysis. J Inf Secur 81:e16-e25. https://doi.org/10.1016/j. jinf.2020.04.021

Zhou F, Yu T, Du R (2020) Clinical course and risk factors for mortality of adult in patients with COVID-19 in Wuhan, China: a retrospective cohort study. Lancet. 395:1054-1062. https://doi.org/10.1016/ S0140-6736(20)30566-3

Zhu L, She ZG, Cheng X (2020) Association of blood glucose control and outcomes in patients with COVID-19 and pre-existing type 2 diabetes. Cell Metab. 31(6):1068-1077.e3. 10.1016/ j.cmet.2020.04.021.

Zietz M, Tatonetti NP (2020) Testing the association between blood type and COVID-19 infection, intubation, and death. MedRxiv. https:// doi.org/10.1101/2020.04.08.20058073.

Publisher's note Springer Nature remains neutral with regard to jurisdictional claims in published maps and institutional affiliations. 